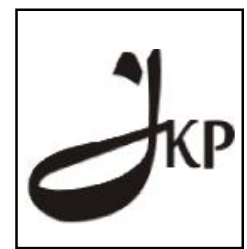

Jurnal Konseling dan Pendidikan

ISSN Cetak: 2337-6740 - ISSN Online: 2337-6880

http://jurnal.konselingindonesia.com

Volume 2 Nomor 2, Juni 2014, HIm 1-8

Info Artikel:

Diterima 06/06/2014

Direvisi 12/06/2014

Dipublikasikan 30/06/2014

Ikatan Konselor Indonesia (IKI)

\title{
Pendalaman Terhadap Masalah Agama, Nilai dan Moral Siswa serta Upaya Penanggulangannya
}

Asri Atuz Zeky

Universitas Negeri Padang

\section{Abstract}

This research aim to to get more complete picture at problem of religion, student moral and value and also strive penanggulangannya in SMP Development of UNP. quantitative descriptive Type Research. used by instrument is enquette, documentation study and interview. Amount of sampel 190 people. Data analysed with percentage. Result of Research indicate that problems of ANM at student generally experience of less obedient in running religion, though they thirst for quit ofly is problem of weight which they experience of, they not yet exploited aid service of teacher, specially learn counsellor. Effort learn counsellor to overcome problems of student have optimal enough, but experience of some constraint. This research have [of] implication to counsellor teacher and subject teacher.

Keyword: Religious Issues, Values and Moral

Copyright ( 2014 IICE - Multikarya Kons (Padang - Indonesia) dan IKI - Ikatan Konselor Indonesia - All Rights Reserved

Indonesian Institute for Counseling and Education (IICE) Multikarya Kons

\section{PENDAHULUAN}

Pada jalur pendidikan tingkat Sekolah Menengah Pertama (SMP), siswa diharapkan dapat memenuhi beberapa tugas perkembangan, di antaranya 1) mencapai perkembangan diri sebagai remaja yang beriman dan bertaqwa kepada Tuhan Yang Maha Esa, 2) memantapkan nilai dan cara bertingkah laku yang dapat diterima dalam kehidupan yang lebih luas, 3) mengenal sistem etika dan nilai-nilai bagi pedoman hidup sebagai pribadi, anggota masyarakat, dan warga negara (Kurikulum Berbasis Kompetensi, 2002:10). Hurlock (1992:185) mengemukakan bahwa pertumbuhan dan perkembangan fisik yang sangat pesat dapat menimbulkan keraguan, perasaan tidak mampu, tidak aman dan dalam banyak kasus mengakibatkan perilaku yang kurang baik. Siswa dengan pemahaman agama, nilai dan moral yang baik seharusnya dapat melewati masa puber. Agama, nilai dan moral (selanjutnya disingkat dengan ANM merupakan sesuatu yang mesti dipahami dan diamalkan serta dijunjung tinggi oleh semua individu termasuk siswa. Namun yang terjadi sekarang adalah keyakinan seseorang terhadap agama sudah mulai longgar, kepercayaan kepada Tuhan hanya tinggal simbol. Berdasarkan hasil wawancara dan pengadministrasian Alat Ungkap Masalah (AUM) di SMP Pembangunan Universitas Negeri Padang, peneliti mendapatkan informasi bahwa masih banyaknya siswa yang tidak mengerjakan sholat, sering terdengar berkata-kata yang tidak baik, baik kepada teman maupun orang tua mereka, sering berkata bohong, berbuat bohong, dan lain-lain. Setelah pengadministrasian AUM yang peneliti lakukan pada bulan Mei 2009, ditemukan bahwa masalah berat ANM yang dialami siswa, yaitu: 1) berkata dusta atau berbohong, 2) terlanjur berbicara, atau melakukan sesuatu yang tidak baik kepada orang tua atau orang lain, 3) mengalami masalah karena takut berdosa melanggar aturan agama, 4) kurang taat dalam menjalankan ibadah agama, dan 5) mengalami kesulitan karena terpaksa mengingkari janji. 


\section{MASALAH-MASALAH SISWA}

\section{Pengertian Masalah dan Karakteristiknya}

WS. Winkel (1997:12) mendefinisikan "masalah adalah sesuatu yang menghambat, merintangi dan mempersulit dalam usaha mencapai suatu tujuan". Prayitno (2003:17) menjelaskan bahwa orang yang mengalami masalah memperlihatkan kemandirian yang terganggu. Ia tidak mengenal dan menerima diri dan lingkungannya dengan baik, tidak mampu mengambil keputusan sehingga pengarahan dirinya terlambat dan akhirnya tidak mampu mewujudkan diri sesuai dengan potensi yang dimilikinya. Prayitno dan Erman Amti (2004:87) lebih lanjut mengemukakan bahwa ciri-ciri suatu masalah, adalah: a) suatu hal yang tidak disukai keberadaannya, b) sesuatu yang ingin dihilangkan keberadaannya, c) sesuatu yang dapat menimbulkan kerugian dan/atau kesulitan baik sekarang maupun akan datang.

Pendapat-pendapat yang telah dipaparkan di atas menunjukkan bahwa masalah adalah sesuatu yang tidak diinginkan terjadi atau diharapkan adanya, karena dapat menimbulkan kesulitan dan kerugian untuk mencapai suatu tujuan tertentu, sehingga bagi orang yang telah menyadari adanya masalah pada dirinya maka ia ingin segera menghilangkannya. Masalah yang dialami siswa dapat ditinjau dari beberapa hal, yaitu rincian masalah, sebab, akibat, sikap siswa, kondisi lingkungan dan upaya siswa dalam menanggulanginya. Berikut ini uraian lebih jelasnya:

\section{Rincian Masalah}

Rincian awal akan memudahkan peneliti untuk membahas lebih lanjut faktor-faktor penyebab adanya masalah yang timbul, akibat dari masalah tersebut, sikap siswa menghadapi masalah, kondisi lingkungan timbulnya masalah dan upaya siswa untuk mengatasi masalah yang ada pada dirinya.

\section{Sebab Timbulnya Masalah}

Faktor-faktor penyebab masalah siswa dalam agama, nilai dan moral ada dua hal, yaitu:

1) Faktor internal, terkait dengan a) matangnya organ seks yang mendorong remaja untuk memenuhi kebutuhan tersebut, namun di sisi lain dia tahu bahwa perbuatan itu dilarang oleh agama, dan b) berkembangnya sikap independen, keinginan untuk hidup bebas, tidak mau terikat dengan norma-norma keluarga, sekolah, atau agama.

2) Faktor eksternal, terkait dengan aspek-aspek a) perkembangan kehidupan sosial budaya dalam masyarakat yang tidak jarang bertentangan dengan nilai-nilai agama, namun sangat menarik minat remaja untuk mencobanya, seperti beredarnya film-film VCD-VCD, atau foto-foto porno, penjualan minuman keras dan alat-alat kontrasepsi yang bebas; dan b) perilaku orang dewasa, orang tua sendiri, para pejabat, dan warga negara yang gaya hidupnya (life style) kurang memperdulikan agama, bersifat munafik, tidak jujur dan prilaku amoral lainnya.

\section{Akibat Masalah}

Akibat-akibat yang dapat ditimbulkan dari masalah yang dialami siswa secara umum adalah akan menimbulkan kerugian dan kesulitan bagi siswa tersebut baik untuk sekarang maupun akan datang.

\section{Sikap Siswa terhadap Masalah}

Sikap dalam arti sempitnya adalah pandangan atau kecendrungan mental (M. Dalyano, 1997:216). Muhibbin Syah (2003:149) berpendapat bahwa kecendrungan yang relatif menetap untuk bereaksi dengan cara baik (positif) atau buruk (negatif) terhadap orang atau hal tertentu.

\section{Kondisi Lingkungan Individu Bermasalah}

Lingkungan sangat besar pengaruhnya terhadap timbulnya permasalahan pada diri seseorang (Prayitno dan Erman Amti, 1990:83). Lingkungan yang baik, akan cenderung membawa individu untuk berlaku baik juga, jika lingkungannya tidak baik, juga akan berpengaruh sangat besar terhadap individu yang berada di sana.

\section{Upaya siswa dalam menanggulangi masalah yang dialaminya}


Adapun penyelesaiannya dapat dilakukan dengan cara yang bermacam-macam. Adakalanya siswa berusaha sendiri menanggulangi masalahnya, membicarakan dengan keluarga, teman, meminta kepada guru bidang studi, atau meminta bantuan kepada guru pembimbing.

\section{Bidang-bidang Masalah}

Prayitno (1997:2), mengelompokkan masalah siswa, yaitu sebagai berikut: 1) Masalah jasmani dan kesehatan (JDK), 2) Masalah diri pribadi (DPI), 3) Masalah hubungan sosial (HSO), 4) Masalah ekonomi dan keuangan (EDK), 5) Masalah karir dan pekerjaan (KDP), 6) Masalah pendidikan dan pekerjaan (PDP), 7) Masalah hubungan muda-mudi (HMM), 8) Masalah agama, nilai, dan moral (ANM), 9) Masalah keadaan dan hubungan dalam keluarga (KHK) dan 10) Masalah waktu senggang (WSG).

\section{BIDANG MASALAH AGAMA, NILAI, DAN MORAL (ANM)}

\section{Ruang lingkup Masalah Agama, Nilai dan Moral}

\section{Masalah Agama}

Perkembangan agama pada remaja dipengaruhi berbagai hal, diantaranya adalah karena perkembangan pikiran, mental, perasaan, sosial, sikap dan minatnya. Jika hal tersebut dibina dengan baik pada masa kecil, maka perkembangan mereka pada masa remaja tidak akan mengalami permasalahan yang berarti.

\section{Masalah Nilai}

Nilai merupakan suatu hal yang penting dan diperjuangkan oleh seseorang dalam hidup, yang akan mengantarkan hidupnya pada puncak kemuliaan sebagai manusia terbaik di hadapan Tuhan maupun di hadapan manusia. Kesesuaian antara suatu nilai yang dianut masyarakat dengan prilaku atau kebiasaan individu berarti individu tersebut telah memahami dan telah melaksanakan suatu nilai.

\section{Masalah Moral}

Konteks agama Islam menyatakan bahwa moral keagamaan ada dua: 1) moral keagamaan terhadap Allah/ hablumminallah dan 2) moral keagamaan antara manusia sesama manusia/ hablumminannas. Selanjutnya Jalaluddin (2000:74) menyebutkan bahwa perkembangan moral para remaja bertitik tolak dari rasa berdosa dan usaha untuk mencari proteksi.

\section{Keterkaitan Masalah Agama, Nilai dan Moral}

Permasalahan agama, nilai dan moral memiliki keterkaitan yang erat. Hal ini disebabkan pada intinya agama mengandung nilai-nilai dan moral yang harus dipatuhi oleh manusia. Pelanggaran yang dialami siswa berkenaan dengan pelanggaran nilai dan moral, hampir dapat dipastikan juga melakukan pelanggaran dalam agama. Hal ini dikarenakan agama pada dasarnya berintikan nilai-nilai dan moral yang harus ditaati oleh pemeluknya.

\section{Jenis-jenis Masalah Bidang Agama, Nilai dan Moral Siswa}

Jenis-jenis masalah bidang ANM, terdapat dalam AUM Umum format-3 untuk SLTP terdiri dari 15 jenis masalah (Prayitno, dkk, 2001) yang dikelompokkan sebagai berikut:

a. Masalah Agama

1) Tidak suka pergi ke tempat peribadatan

2) Sering mengerjakan hal-hal yang dilarang oleh agama

3) Mengalami masalah karena dalam keluarga ada yang tidak seagama

4) Mengalami masalah karena takut berdosa melanggar aturan agama

5) Kurang taat dalam menjalankan ibadah agama 
b. Masalah Nilai

1) Berbuat tidak jujur

2) Berkata dusta atau berbohong

3) Sukar membedakan yang dianggap yang dianggap baik atau buruk

4) Tidak melaksanakan apa yang menjadi tanggung jawab sendiri

5) Mengalami masalah karena memiliki kebiasaan yang berbeda dengan orang lain

c. Masalah Moral

1) Terlanjur berbicara, atau melakukan sesuatu yang tidak baik kepada orang tua atau orang lain

2) Sering ditegur karena melakukan kesalahan

3) Terlanjur berolok-olok yang menyebabkan orang lain tidak senang

4) Terlanjur melakukan sesuatu perbuatan yang salah

5) Mengalami kesulitan karena terpaksa mengingkari janji

Penjelasan tentang masalah-masalah bidang ANM di atas terbatas pada masalah-masalah yang diteliti. Yang peneliti teliti mencakup 5 aspek, yaitu tentang:

a. Berkata dusta atau berbohong

b. Terlanjur berbicara, atau melakukan sesuatu yang tidak baik kepada orang tua atau orang lain

c. Mengalami masalah karena takut berdosa melanggar aturan agama

d. Kurang taat dalam menjalankan ibadah agama

e. Mengalami kesulitan karena terpaksa mengingkari janji

\section{Upaya Penanggulangan oleh Guru Pembimbing}

Guru pembimbing adalah guru yang mempunyai tugas, tanggung jawab, wewenang dan hak secara penuh dalam kegiatan bimbingan dan konseling terhadap sejumlah peserta didik. Pelayanan bimbingan dan konseling di sekolah merupakan kegiatan untuk membantu siswa dalam upaya menemukan dirinya, penyesuaian terhadap lingkungan serta dapat merencanakan masa depannya. Undang-undang Nomor 20 Tahun 2003 menyatakan "guru pembimbing adalah pendidik" dan dalam Peraturan Menteri Pendidikan Nasional Nomor 22 Tahun 2005 mengemukakan "guru pembimbing adalah pelaksana pelayanan konseling di sekolah.

\section{METODOLOGI}

Jenis penelitian deskriptif kuantitatif tujuannya untuk mengungkapkan tentang gejala dan kajian apa adanya tentang ANM siswa. Populasi dalam penelitian ini adalah siswa kelas I dan II SMP Pembangunan Universitas Negeri Padang, yaitu kelas I berjumlah 173 orang dan kelas II berjumlah 200 orang. Jadi jumlah populasi 373 orang. Dalam penelitian ini dilakukan dua kali penarikan sampel yaitu dengan teknik Stratified Proportional Random Sampling, setelah data diperoleh maka dilakukan penarikan sampel ke dua dengan purposive sampling, yaitu penarikan sampel yang dilakukan berdasarkan maksud tertentu, sehingga dalam penelitian ini diperoleh sampel khusus kepada siswa yang mengalami masalah berat yaitu pada masalah 1) berkata dusta atau berbohong (nomor 015) sebanyak 90 orang, 2) terlanjur berbicara, atau melakukan sesuatu yang tidak baik kepada orang tua atau orang lain (nomor 026) sebanyak 134 orang, 3) mengalami masalah karena takut berdosa melanggar aturan agama (nomor 28) sebanyak 158 orang, 4) kurang taat dalam menjalankan ibadah agama (nomor 030) sebanyak 165 orang, dan 5) mengalami kesulitan karena terpaksa mengingkari janji (nomor 45) sebanyak 82 orang. 


\section{HASIL DAN PEMBAHASAN}

Pendalaman Masalah Bidang Agama, Nilai dan Moral (ANM)

Pendalaman masalah ANM siswa berdasarkan tingkatan kelas dan jenis kelamin tidak begitu berbeda. Pendalaman masalahan dalam hal:

1. "Suka berdusta/ berbohong" (AUM nomor 015). Berdasarkan data yang diperoleh terungkap bahwa pada masalah ini siswa lebih banyak berdusta kepada teman. Hal ini disebabkan karena sekedar berolok-olok, akibatnya siswa menyesal dan merasa bersalah. Oleh karena itu sebenarnya siswa tidak menyukai sikap dusta ini, tetapi karena kondisi lingkungan (meniru dari televisi, film, internet atau sejenisnya) sangat mempengaruhi perilaku siswa. Dalam hal ini upaya yang dapat dilakukan siswa adalah berusaha untuk tidak berbohong lagi.

2. "Terlanjur berbicara, atau melakukan sesuatu yang tidak baik kepada orang tua atau orang lain" (AUM Nomor 026). Berdasarkan data yang diperoleh terungkap bahwa pada masalah ini siswa lebih banyak suka membantah. Hal ini disebabkan karena siswa terlalu sering dimarahi, akibatnya siswa menyesal, merasa bersalah dan berdosa. Sebenarnya siswa tidak menyukai sikap ini, tetapi karena orang tua tidak mengerti yang diinginkan, sehingga siswa melakukan perbuatan tersebut. Untuk menanggulangi masalah ini siswa menyatakan segera minta maaf."Mengalami masalah karena takut berdosa melanggar aturan agama" (AUM Nomor 028. Berdasarkan data yang diperoleh terungkap bahwa pada masalah ini siswa lebih banyak suka menonton VCD porno. Hal ini disebabkan karena ikut-ikutan teman. Akibatnya siswa menyatakan hidupnya tidak nyaman, merasa bersalah dan berdosa. Sebenarnya siswa tidak ingin adanya masalah tersebut, tetapi kondisi lingkungan yang mendukung untuk melakukan perbuatan tersebut. Untuk menanggulangi masalah ini siswa menyatakan ingin bertobat kepada Allah."Kurang taat dalam menjalankan ibadah agama" (AUM Nomor 030). Berdasarkan data yang diperoleh terungkap bahwa pada masalah ini siswa sering tidak mengerjakan sholat, dikarenakan malas melaksanakannya. Akibatnya, hati menjadi gelisah dan merasa berdosa. Sebenarnya siswa tidak ingin adanya masalah tersebut, tetapi karena ketika rajin sholat saudara mengejek. Untuk menanggulangi masalah ini siswa menyatakan akan berusaha untuk mendalami agama.

3. "Mengalami kesulitan karena terpaksa mengingkari janji" (AUM Nomor 045), Berdasarkan data yang diperoleh terungkap bahwa pada masalah ini siswa terpaksa mengingkari janji kepada temannya karena sering lupa. Akibat yang dirasakan adalah adanya rasa dikejar-kejar rasa bersalah. Sebenarnya siswa tidak ingin adanya masalah tersebut, tetapi karena orang tua tidak mengizinkan pergi, makanya terpaksa mengingkari janji. Untuk menanggulangi masalah ini siswa menyatakan akan berusaha untuk menepati janjinya.

\section{Upaya Penanggulangan Masalah Agama, Nilai dan Moral (ANM) Siswa oleh Guru BK/Konselor}

Guru pembimbing sudah berusaha untuk menjalankan tugas-tugasnya, namun menemui beberapa kendala diantaranya tidak sebandingnya jumlah guru pembimbing dengan jumlah siswa (belum sesuai dengan yang ideal), kekurangmampuan guru pembimbing melaksanakan program secara baik, belum mampu menyamakan persepsi terhadap tugas, dan belum mampu menjalin kerjasama secara baik dan terprogram dengan guru-guru lain yang terkait. Termasuk juga yang menjadi kendala yaitu keterbatasan dari segi waktu, dana dan dukungan dari pihak sekolah.

\section{PEMBAHASAN}

Pendalaman Masalah Bidang Agama, Nilai dan Moral (ANM)

1. Pendalaman masalah "Suka berdusta/ berbohong"

Para ulama berpendapat bahwa, "kejujuran itu adalah pedang Allah di muka bumi, tidak sesuatupun yang diletakkan di atasnya melainkan ia pasti memotongnya". Yusuf bin Asbath dan yang lainnya berkata, "Tidaklah seorang hamba berlaku jujur kepada Allah melainkan kejujuran itu akan kembali kepadanya". 
(Syaikhul Islam Ibnu Taimiyah, 2008: 181). M. Ali al-Hasyimi (2000: 400), juga menyatakan bahwa kejujuran menuntut sikap tulus, terus terang, setia dan adil yang tidak menyisakan ruang untuk berdusta, menipu, bermuslihat atau berkhianat.

2. Pendalaman masalah "Terlanjur berbicara, atau melakukan sesuatu yang tidak baik kepada orang tua atau orang lain"

Untuk mengetahui dalil tentang larangan suka berolok-olok dan mengejek dapat dilihat dalam alQur'an surat al-Hujurat ayat 11, yang artinya:

"Wahai orang-orang yang beriman! Janganlah suatu kaum mengolok-olok kaum yang lain, karena boleh jadi mereka (yang diperolok-olokan) lebih baik dari mereka (yang mengolok-olok), dan jangan pula perempuan-perempuan (mengolok-olokkan) perempuan lain, (karena) boleh jadi perempuan (yang diperolok-olok) lebih baik dari perempuan (yang mengolok-olok). Janganlah kamu saling mencela satu sama lain dan janganlah saling memanggil dengan panggilan yang buruk. Seburukburuk panggilan adalah (panggilan) yang buruk (faskl) setelah beriman. Dan barang siapa tidak bertobat, maka mereka itulah orang-orang yang zalim.

Pada ayat ini, dijelaskan larangan untuk saling memperolok karena belum tentu yang memperolok lebih baik dari pada yang diperolok ataupun sebaliknya. Juga ayat ini melarang saling mengejek dan memberi gelar nama dengan panggilan yang buruk.

3. Pendalaman masalah "Mengalami masalah karena takut berdosa melanggar aturan agama"

VCD porno merupakan salah satu bentuk dari pornografi. Pornografi dapat diidentifikasi sebagai penyakit melemahkan ikatan-ikatan moral dan mendorong timbulnya pola kehidupan baru yang cendrung primitif dan hedonistik (Abdul Hasim Fatan, 2008: 46). Pada masa remaja kelompok teman sebaya sangat berpengaruh melebihi pengaruh orang tua (Alwi Alatas, 2005:58). Remaja zaman sekarang ini cendrung menjadikan teman mereka sebagai tempat berbagi, termasuk hal-hal yang bersifat pribadi dan rahasia.

4. Pendalaman masalah "Kurang taat dalam menjalankan ibadah agama"

Malas karena terbiasa meninggalkan dan mengikuti kemalasannya maka terbiasalah dia meninggalkan shalat (Indah Mulya, dalam http: //mimbarjumat. com/archives/130). Malas adalah merasa berat dari sesuatu yang tidak semestinya, karena itu ia menjadi tercela (M. Yusuf 'Abdul bin Hasan (2008:231). Dalam alQur'an surat al-Ma'un ayat 5-7 juga mengancam orang-orang yang malas dalam shalatnya, yang artinya adalah : "Maka celakalah orang yang shalat, (yaitu) orang-orang yang lalai dalam shalatnya, yang berbuat ria dan enggan (memberikan) bantuan”.

Ayat di atas mengemukakan bahwa kecelakaan bagi orang-orang yang sholat, yaitu orang-orang yang lalai dalam sholatnya. Jadi Allah sangat mengancam keberadaan orang-orang yang lalai dalam sholatnya. Baik itu lalai dalam waktu melaksanakannya ataupun lalai ketika sedang melaksanakan sholat. Ada yang menyatakan penyebabnya adalah karena kurangnya pengetahuan agama, padahal salah satu syarat untuk melaksanakan tuntutan agama adalah memiliki ilmu pengetahuan. Agama berangkat dari ilmu pengetahuan. Ilmu pengetahuan memberi kesempatan kepada seseorang untuk membedakan apa yang baik dilakukan dan yang tidak, karena ia merupakan lentera (penerang) jalan menuju surga. Dengan ilmu pengetahuan, hamba Allah mendapat posisi yang mulai dan terhormat dengan dilai kebaikan yang tinggi (Syed Ameer Ali, 1994: 67). Misalnya ibadah sholat, untuk dapat melaksanakan sholat dengan baik dan benar, pengetahuan tentang sholat harus dimiliki terlebih dahulu, mulai dari konsep, rukun, syarat, hal-hal yang membatalkan, sampai kepada hikmah yang dikandung ibadah sholat tersebut.

5. Pendalaman masalah "Mengalami kesulitan karena terpaksa mengingkari janji"

Siapa saja yang telah berjanji kepada sesama manusia, entah itu berkenaan dengan janji membayar hutang, memenuhi undangan, berkumpul di suatu tempat dan sebagainya, maka janji-janji itu harus dipenuhi dan tak boleh diingkari (http://www.geocities.com/by_ibnoe/ cerita/menepati_janji.htm+menepati+janji). Tidak ada ruang untuk berdalih atau melarikan diri dari tanggung jawab, karena tugas seorang muslim adalah teguh memegang janjinya (M. Ali al-Hasyimi, 2000:2-3). 
Upaya guru pembimbing mengungkapkan masalah ANM siswa di SMP Pembangunan UNP sepertinya sudah sesuai dengan yang dikemukakan oleh Prayitno dan Amti (1999:197), bahwa prosedur penanganan masalah dimulai dari pemahaman, penanganan, sampai kepada penyikapan. Pemahaman masalah dilihat dari rincian masalah, sebab-sebab dan akibat-akibatnya. Penanganan masalah dimulai dengan pengungkapan, pengembangan ide-ide, penjelajahan, serta upaya-upaya khusus. Sedangkan penyikapan mencakup aspek kognisi, afeksi dan perlakuan.

Persoalannya adalah meskipun guru pembimbing telah berupaya mengungkapkan masalah ANM siswa dengan berbagai cara, namun tidak semua masalah siswa terdeteksi dengan baik, disebabkan terbatasnya interaksi antara guru pembimbing dengan siswa di sekolah. Salah satu cara yang dapat di tempuh untuk menghadapi kondisi ini adalah membangun kerjasama yang harmonis dan terprogram dengan orang tua siswa dan masyarakat. Dengan mengefektifkan fungsi kontrol terhadap kecendrungan siswa sehari-hari.

\section{PENUTUP}

Pendalaman masalah ANM siswa berdasarkan tingkatan kelas dan jenis kelamin tidak begitu berbeda, jika ditinjau dari: a) rincian masalah, pada umumnya adalah dalam hal siswa suka berdusta/ berbohong kepada teman, suka membantah, suka menonton VCD porno, sholat sering tidak dikerjakan, dan terpaksa mengingkari janji kepada teman; b) sebab timbulnya masalah karena siswa tidak ada maksud apa-apa, sering dimarahi, ikutikutan teman, malas melaksanakannya, dan sering lupa; c) akibatnya bagi siswa adalah ada rasa penyesalan, hati gelisah dan berdosa; d) sikap siswa menunjukkan bahwa semuanya tidak ingin adanya masalah tersebut; e) kondisi lingkungan yang dihadapi karena meniru dari media (TV, internet/ yang sejenisnya), orang tua tidak mengerti yang diinginkan, suasana mendukung untuk melakukan perbuatan tersebut, ketika rajin berbuat baik saudara mengejek dan ketika akan pergi orang tua tidak mengizinkan, f) Dalam menanggulangi masalah, umumnya siswa berusaha menanggulanginya sendiri, dan hanya sedikit yang membicarakannya dengan orang tua (anggota keluarga) dan meminta bantuan pada guru pembimbing. Upaya guru pembimbing untuk mengatasi permasalahan siswa sudah cukup optimal, namun mengalami beberapa kendala dan diperlukan adanya kerjasama dengan personil sekolah yang lain.

Saran

Berdasarkan simpulan di atas, maka disarankan kepada berbagai pihak sebagai berikut, kepada:

1. Dinas pendidikan kota Padang untuk merumuskan dan mengambil kebijakan tentang waktu masuk kelas bimbingan dan konseling.

2. Pengawas pendidikan, agar memberikan supervisi dalam bidang bimbingan dan konseling.

3. Kepala Sekolah, lebih memberikan perhatian, khususnya pada jalannya program bimbingan dan konseling.

4. Unit bimbingan dan konseling di sekolah melaksanakan layanan bimbingan dan konseling lebih aktif dan gencar.

5. Guru pembimbing hendaknya dapat mendalami masalah ANM siswa dan berupaya keras mensosialisasikan dan memotivasi siswa dalam memanfaatkan layanan bimbingan dan konseling.

6. Siswa, agar lebih mempertinggi kepedulian dan mempraktekkan pendidikan agama, sehingga akan terwujud nilai dan moral yang baik pada dirinya.

7. Orang tua, agar lebih memperhatikan dan membimbing anak-anak mereka yang mengalami masalah agama, nilai dan moral.

8. Peneliti lain, untuk dapat melanjutkan penelitian ini kepada sampel yang lebih luas, khususnya yang berkaitan dengan masalah ANM. 


\section{DAFTAR PUSTAKA}

A. Muri Yusuf. 2005. Metode Penelitian: Dasar-dasar Penyelidikan Ilmiah. Padang: UNP Press.

Alwi Alatas. 2005. Remaja Juga Bisa Bahagia, Sukses dan Mandiri. Jakarta Selatan: Pena Pundi Aksara

Departemen Agama RI. 2005. Mushaf Al Qur'an Terjemah. Jakarta: Al-Huda

Hurlock, Elizabeth B. 1980. Psikologi Perkembangan: Suatu Pendekatan Sepanjang Rentang Kehidupan. Edisi Kelima. Terjemahan oleh Istiwidayanti. Jakarta: Erlangga

Indah Mulya. 2008. Shalat adalah Bentuk Ketaatan kepada Allah, (Online), (http: // mimbarjumat. com/ archives/ 130S, diakses 7 Maret 2009)

Al-Islam. Pusat Informasi dan Komunikasi Islam Indonesia. 2009. Cerita Menepati Janji, (Online), (http:// www. geocities.com/ by_ibnoe/ cerita/menepati_janji.htm+ menepati+janji, diakses 25 Juli 2009)

Jalaluddin. 2000. Psikologi Agama. Jakarta: PT. Grafindo Persada

M. Ali al-Hasyimi. 2000. Muslimah Ideal Pribadi Islam dalam al-Qur'an dan as-Sunnah. Yogyakarta: Mitra Pustaka

M. Dalyono. 1997. Psikologi Pendidikan. Jakarta: Rineka Cipta

M. Yusuf 'Abdu bin Hasan. 2008. Jangan Jadi Munafik! Siapa Saja bisa jadi Munafik. Bandung: Pustaka Hidayah

Muhibbin Syah. 2003. Psikologi Belajar. Jakarta: PT. Grafindo Persada

Prayitno dan Erman Amti. 1990. Profil Lembaga Pendidikan bagi Pembentukan Akhlak Bangsa. (Makalah)

Prayitno dan Erman Amti. 2004. Dasar-dasar Bimbingan dan Konseling. Jakarta: PT. Rineka Cipta

Prayitno, dkk. 2000. AUM Seri Umum Format: SMP. Padang: FIP-UNP

Syaikhul Islam Ibnu Taimiyah. 2008. Tazkiyatun Nafs. Jakarta: Darus Sunnah

W.S. Winkel. 1997. Bimbingan dan Konseling di Institusi Pendidikan. Jakarta: CV. Gramedia 